\title{
PERLINDUNGAN HUKUM TERHADAP BANK SEBAGAI PEMEGANG JAMINAN KEBENDAAN TERKAIT PELUNASAN HUTANG OLEH DEBITOR (STUDI KASUS PUTUSAN No.50/Pailit/2010/PN.Niaga.JKT.PST)
}

\author{
Wilda Prima Putri
}

Program Studi Magister Kenotariatan, Fakultas Hukum, Universitas Brawijaya

\begin{abstract}
ABSTRAK
Nasabah debitor dalam pelaksanaan perjanjian kredit bank dapat mengalami kesulitan untuk tidak dapat melaksanakan kewajibannya kepada bank kreditor karena mengalami kepailitan. Akibatnya permasalahan muncul terkait bagaimana perlindungan hukum terhadap bank misalnya Bank BNI sebagai pemegang jaminan kebendaan untuk memperoleh pelunasan piutang terhadap para debitor yang dinyatakan pailit oleh Pengadilan Niaga; dan bagaimana upaya hukum yang dapat ditempuh oleh Bank BNI sebagai pemegang jaminan kebendaan agar debitor pailit dapat melunasi utangnya. Hasil analisis menunjukkan bahwa walaupun instrumen hukum kepailitan berdasarkan UU PKPU tidak dapat sepenuhnya memberikan perlindungan hukum kepada bank sebagai kreditor pemegang jaminan kebendaan untuk memperoleh keseluruhan hak-haknya melalui mekanisme penyelesaian piutang oleh kurator sampai saat berakhirnya kepailitan. Bank BNI belum melengkapi dengan regulasi, akta-akta dan persyaratan-persyaratan tambahan guna melindungi kepentingan bagi pelunasan seluruh piutangnya ketika terjadi kepailitan debitornya. Pembatasan waktu bagi bank sebagai kreditor pemegang jaminan kebendaan untuk melakukan hak eksekusinya mengakibatkan UU PKPU tidak cukup efektif untuk memberikan perlindungan hukum kepada bank sebagai kreditor pemegang jaminan kebendaan. Kata Kunci: mekanisme penyelesaian, piutang, kurator, kreditor, debitor
\end{abstract}

\begin{abstract}
Debtor may experience difficulties to not be able to carry out their obligations to creditor banks due to bankruptcy. As the result, it would be an issue on how the laws could provide legal protection for banks, such as Bank BNI, in order to receive the credit payment paid by bankrupt debtor and how legal remedies can be taken by Bank BNI as a holder of material guarantees so that bankrupt debtors can repay their debts. The analysis shows that bankruptcy legal instruments based on the PKPU Law cannot fully provide legal protection to banks as creditors. Bank BNI has not met the conditions determined by the regulations, deeds and additional requirements to protect the interests of repayment of all receivables when the debtor's bankruptcy occurs. The due date on which the creditors carry out their rights has resulted in ineffective legal instrument to provide protection for bank as creditors.
\end{abstract}

Keywords: settlement mechanism, accounts receivable, curator, creditor, debtor, 


\section{PENDAHULUAN}

Perekonomian dan perdagangan yang mengalami perkembangan serta globalisasi yang melanda dunia telah berpengaruh terhadap usaha dewasa ini. Namun, pada umumnya sebagian besar modal yang dipergunakan para pengusaha adalah pinjaman yang berasal dari bermacam-macam sumber termasuk lembaga perbankan. Kredit bank ternyata menimbulkan begitu banyak problema dalam penyelesaian utang piutang. Bank Berdasarkan Pasal 1 angka 2 Undang-Undang Nomor 7 Tahun 1992 tentang Perbankan sebagaimana telah diganti oleh UndangUndang Nomor 10 Tahun 1998. (UU No. 7 Tahun 1992). ${ }^{1}$ adalah sebuah badan usaha yang melakukan penghimpunan dana yang berasal dari masyarakat dalam bentuk simpanan.

Dana yang dihimpun selanjutnya disalurkan kepada masyarakat dalam bentuk kredit dan bentuk-bentuk lain. Kredit berdasarkan Pasal 1 butir 11 UU No. 7 Tahun 1992, adalah penyediaan uang dan tagihan-tagihan yang dapat dipersamakan. Penyediaan tersebut dilaksanakan dengan kesepakatan atau persetujuan pinjam-meminjam yang dilakukan antara bank dengan pihak lain. Kesepakatan tersebut menimbulkan akibat terhadap peminjam yang disebut debitor atau nasabah debitor untuk melunasi utangnya setelah waktu telah ditentukan beserta dengan bunga yang telah dijanjikan.

Nasabah debitor ${ }^{2}$ dalam pelaksanaan perjanjian kredit bank, dapat mengalami kesulitan usaha sehingga berdampak pada kemampuannya untuk melaksanakan kewajibannya membayar utangnya kepada bank kreditor karena mengalami kepailitan. ${ }^{3}$ Kewajiban tersebut adalah pelunasan utang, yaitu

\footnotetext{
${ }^{1}$ Undang-Undang Republik Indonesia Nomor 7 Tahun 1992 tentang Perbankan Sebagaimana Telah Diubah dengan Undang-Undang Nomor 10 Tahun 1998.

${ }^{2}$ Berdasarkan Pasal 1 butir 18 Ibid., nasabah debitor merupakan nasabah yang mendapatkan fasilitas kredit atau pembiayaan menurut prinsip syariah atau yang dipersamakan dengan itu berdasarkan perjanjian bank dengan nasabah yang bersangkutan.

${ }^{3}$ Black's Law Dictionary mengartikan kepailitan (bankruptcy): The state or condition of one who is a bankrupt; the condition of one who has commited an act of bankruptcy, and is liable to be proceeded against by his creditors therefor, or of one whose circumtances are such that he is entitled, on his voluntary application, to take the benefit of the bankrupt laws. The term is used in a looser sense as synonymous with "insolvency." (suatu kenyataan atau keadaan seseorang atau yang berada dalam keadaan bangkrut; keadaan seseorang yang telah melakukan perbuatan terkait kebangkrutan, dan bertanggung jawab untuk diproses oleh para kreditornya, atau keadaankeadaan yang sedemikian rupa sehingga dia berhak atas permohonan sukarela untuk memperoleh manfaat dari aturan-aturan dalam hukum kepailitan. Istilah ini dalam pengertian yang lebih
} 
kewajiban sejumlah uang dalam mata uang Indonesia atau mata uang asing. Kewajiban tersebut timbul karena perjanjian atau Undang-Undang. Kewajiban tersebut wajib dipenuhi oleh debitor, sebab bila tidak dipenuhi, maka berarti memberikan kepada kreditor hak untuk mendapat pemenuhannya yang berasal dari kekayaan debitor.

Menurut Sutan Remy Sjahdeini, utang seyogianya tidak diberi makna atau arti yang sempit sebagaimana di dalam UU No. 4 Tahun 1996 tentang Hak Tanggungan Atas Tanah Beserta Benda-benda yang Berkaitan Dengan Tanah, yaitu kewajiban untuk membayar utang akibat adanya perjanjian utang-piutang saja. Sjahdeini memberi makna utang adalah setiap kewajiban debitor yang berupa kewajiban untuk membayar sejumlah uang kepada kreditor, baik kewajiban itu timbul karena perjanjian apa pun juga (tidak terbatas hanya kepada perjanjian utang piutang saja), maupun yang muncul karena Undang-Undang, dan akibat putusan hakim yang telah memiliki kekuatan hukum tetap. ${ }^{4}$ Pengertian utang juga dikemukakan oleh Kartini dan Gunawan Widjaja, yaitu sebagai prestasi atau kewajiban di bidang harta kekayaan yang harus dilakukan debitor. Bila kewajiban tidak dipenuhi oleh debitor, maka kreditor berhak mendapat pemenuhannya dari harta debitor. Pada dasarnya UU Kepailitan tidak hanya membatasi utang sebagai suatu bentuk utang yang bersumber dari perjanjian pinjam-meminjam uang saja. ${ }^{5}$

Bank sebagai pemegang hak jaminan kebendaan dapat dikategorikan sebagai kreditor separatis dapat melaksanakan haknya seolah-olah tidak terjadi kepailitan. ${ }^{6}$ Bank demikian merupakan kreditor pemegang jaminan fidusia, gadai, hak tanggungan dan hipotek, dapat menjamin pemenuhan atas piutangnya. Kreditor pemegang jaminan kebendaan memiliki keistimewaan dalam kedudukan sebagaimana diberikan oleh undang-undang berdasarkan suatu perjanjian, yaitu perjanjian pengikatan jaminan. ${ }^{7}$

longgar dapat disamakan dengan insolvensi). Pada https://thelawdictionary.org. Diakses 10 Oktober 2018.

${ }^{4}$ Sutan Remi Sjahdeini dalam Jono, Hukum Kepailitan, (Jakarta: Sinar Grafika, 2008), hal. $10-11$.

${ }^{5}$ Kartini dan Gunawan Widjaja dalam Jono, Ibid.

${ }^{6}$ Ibid.

${ }^{7}$ Man S. Sastrawidjaja, Hukum Kepailitan dan Penundaan Kewajiban Pembayaran Utang, (Bandung: PT Alumni, 2006), hal. 127. 
Kenyataan dalam praktik hukum kepailitan menunjukkan bahwa jarang sekali kreditor separatis secara sendiri melaksanakan hak eksekusi terhadap jaminan kebendaan miliknya. Meskipun UU PKPU memberikan kemungkinan untuk itu, namun dalam kenyataannya tidak mudah diterapkan. Problemnya adalah mengenai jangka waktu pelaksanaan hak eksekusi yang sampai saat ini masih menjadi perdebatan. Problema lain terkait dengan apakah hak eksekusi yang dimiliki oleh kreditor separatis adalah sejak debitor pailit dinyatakan dalam keadaan insolvensi hingga paling lambat 2 (dua) bulan sesudah mulai insolvensi. Ini berarti bahwa kesempatan kreditor separatis melaksanakan hak eksekusi hanya 2 (dua) bulan. Jangka waktu tersebut relatif amat singkat bagi bank untuk mengeksekusi jaminan kredit, karena sering sulit mencari calon pembeli pada lelang atau penjualan umum.

Akibat tidak dapat dilakukannya eksekusi tersebut, barang jaminan kebendaan harus diserahkan kepada kurator yang ditunjuk oleh pengadilan, sehingga barang jaminan menjadi masuk dalam harta pailit. Konsekuensinya, bank sebagai kreditor separatis akhirnya menjadi kreditor lainnya yang tidak memiliki hak jaminan kebendaan. Konsekuensi ini tentu dirasakan oleh bank kreditor menjadi tidak adil. Oleh sebab itu Bank sebagai kreditor pemegang jaminan kebendaan yang walaupun memiliki jaminan kebendaan (kreditor pemegang jaminan fidusia, gadai, hak tanggungan dan hipotek) untuk menjamin pemenuhan atas piutangnya, tetap lebih berupaya untuk memenuhi haknya terhadap debitor. Dalam kaitan ini Bank sebagai kreditor pemegang jaminan kebendaan dapat melakukan penagihan terhadap total tagihan debitor.

Contoh kasus sebuah bank, yaitu PT Bank Negara Indonesia (Persero) Tbk (Bank BNI) yang berupaya memperoleh seluruh haknya sebagai kreditor pemegang jaminan kebendaaan. Dalam kasus ini Bank BNI tidak termasuk sebagai pihak yang mengajukan permohonan kepailitan terhadap para debitornya melalui mekanisme penyelesaian piutang oleh kurator. Kasus yang dimaksud adalah CV. Mekar Mandiri Plasindo dan H. Sopiah sebagai dua kreditor berkategori kreditor konkuren yang mengajukan gugatan terhadap: (i) CV. Dewi Jaya Lestari; dan (ii) Ny. Sarina. CV. Mekar Mandiri Plasindo adalah perusahaan yang bergerak dalam bidang usaha perdagangan umum, jasa yang juga adalah 
salah satu penyedia bahan baku biji plastik untuk keperluan produksi karung plastik. Di sisi lain, CV. Dewi Jaya Lestari dan Ny. Sarina adalah perusahaan berbentuk badan hukum yang memproduksi karung plastik yang berlokasi di Bandung Kulon untuk dipasarkan dan didistribusikan di dalam negeri. ${ }^{8}$ Terhadap gugatan tersebut, Pengadilan Niaga pada Pengadilan Negeri Jakarta Pusat dalam Putusan No. 50/Pailit/2010/PN.Niaga.Jkt.Pst. tanggal 23 Agustus 2010 menyatakan bahwa CV. Dewi Jaya Lestari dan Ny. Sarina dalam keadaan pailit dengan segala akibat hukumnya. ${ }^{9}$

Kasus ini bermula ketika CV. Mekar Mandiri Plasindo selaku pemasok dan CV. Dewi Jaya Lestari dan Ny. Sarina selaku pemesan barang telah bersepakat untuk melakukan pengiriman dan pemesanan barang terhadap kebutuhan CV. Dewi Jaya Lestari dan Ny. Sarina. Pemesanan barang dilakukan dengan cara mengambil langsung di gudang CV. Mekar Mandiri Plasindo dengan Surat Jalan yang ditandatangani oleh karyawan CV. Dewi Jaya Lestari dan Ny. Sarina. CV. Mekar Mandiri Plasindo dalam pengiriman tersebut sekaligus juga memberikan surat tagihan kepada CV. Dewi Jaya Lestari dan Ny. Sarina sesuai dengan jumlah barang yang diambil pada waktu itu. Apabila barang telah diambil oleh CV. Dewi Jaya Lestari dan Ny. Sarina, maka selang beberapa hari kemudian CV. Dewi Jaya Lestari dan Ny. Sarina berkewajiban melakukan pembayaran tunai sesuai dengan nilai yang tertera pada surat tagihan tersebut.

Terkait dengan kesepakatan ini, CV. Mekar Mandiri Plasindo berkewajiban untuk menyediakan barang sesuai permintaan CV. Dewi Jaya Lestari dan Ny. Sarina, sedangkan kewajiban CV. Dewi Jaya Lestari dan Ny. Sarina adalah melakukan pembayaran langsung terhadap barang yang diambil dari CV. Mekar

${ }^{8}$ Putusan Pailit Nomor: 50/Pailit/2010/PN.Niaga.JKT.PST, hal. 2.

${ }^{9}$ Berdasarkan Penetapan Nomor: 50/Pailit/2010/PN.Niaga.Jkt.Pst., tanggal 22 Oktober 2010, Hakim Pengawas menetapkan bahwa dalam rapat pencocokan piutang, CV. Dewi Jaya Lestari CV. Dewi Jaya Lestari dan Ny. Sarina (dalam pailit) tidak mengajukan perdamaian. Juga dalam rapat verifikasi, ternyata hutang pailit lebih besar daripada harta pailit, sehingga Debitor dalam keadaan tidak mampu membayar hutangnya. Selanjutnya, mengacu pada ketentuan Pasal 178 ayat (1) UU PKPU, yang menyatakan bahwa apabila dalam rapat pencocokan piutang oleh Debitor tidak ditawarkan rencana perdamaian, maka demi hukum, harta pailit berada dalam keadaan insolvensi. Hakim Pengawas dalam penetapannya, menyatakan bahwa Debitor pailit CV. Dewi Jaya Lestari dan Ny. Sarina dalam keadaan insolvensi. Pada tahun 2012 Kepailitan berakhir, dan Hakim Pengawas perkara No. 50/Pailit/2010/PN. Niaga.Jkt.Pst. tersebut memberikan ijin kepada Tim Kurator untuk melakukan pengumuman mengenai berakhirnya Kepailitan CV. Dewi Jaya Lestari dan Ny. Sarina (dalam pailit) dalam Berita Negara Republik Indonesia dan 2 (dua) surat kabar harian. 
Mandiri Plasindo. Dengan demikian yang berlaku adalah adanya surat tagihan yang dikeluarkan oleh CV. Mekar Mandiri Plasindo berdasarkan pengmbilan barang oleh CV. Dewi Jaya Lestari dan Ny. Sarina, yang dibuktikan dengan adanya surat jalan sebagai bukti bahwa barang yang dipesan telah diterima. ${ }^{10}$

Selain memiliki dua kreditor konkuren sebagaimana telah disebutkan di atas, ternyata CV. Dewi Jaya Lestari dan Ny. Sarina juga memiliki kreditor lain, yaitu Bank BNI ${ }^{11}$ yang juga berupaya untuk mendapatkan haknya sebagai kreditor pemegang jaminan kebendaan. Dalam kasus yang dianalisis, Bank BNI tidak termasuk sebagai pihak yang mengajukan permohonan kepailitan terhadap CV. Dewi Jaya Lestari dan Ny. Sarina, melainkan sebagai Kreditor pemegang jaminan kebendaan yang berupaya memperoleh haknya di samping kreditor lain yang masuk kategori kreditor konkuren yang juga mempunyai hak istimewa karena diberikan oleh undang-undang.

Putusan Pengadilan Niaga pada Pengadilan Negeri Jakarta Pusat dalam Putusan No. 50/Pailit/2010/PN.Niaga.Jkt.Pst. menyatakan bahwa batas akhir pengajuan tagihan tanggal 6 Oktober 2010 jam 15.00 WIB untuk dan atas nama Bank BNI. Mengacu pada putusan tersebut, Bank BNI pada 23 Agustus 2010 berupaya agar piutangnya dapat dibayarkan oleh debitornya tersebut. Mengacu pada Putusan Pengadilan Niaga tersebut, Bank BNI mengajukan total tagihan pinjaman kepada CV. Dewi Jaya Lestari dan Ny. Sarina sebagai Debitor. Pengajuan tersebut dilakukan Bank BNI kreditor pemegang jaminan kebendaan setelah menerima surat dari tim kurator. ${ }^{12}$

Berdasarkan uraian permasalahan di atas, maka pada kesempatan ini penulis ingin membahas tentang permasalahan hukum dengan judul "Perlindungan Hukum Terhadap Bank Sebagai Pemegang Jaminan Kebendaan Terkait Pelunasan Hutang Oleh Debitor (Studi Kasus Putusan No.50/Pailit/2010/Pn.Niaga.Jkt.Pst)” dengan rumusan masalah:

a. Bagaimana perlindungan hukum terhadap Bank BNI sebagai pemegang jaminan kebendaan untuk memperoleh pelunasan piutang terhadap CV.

\footnotetext{
${ }^{10}$ Ibid., hal. 2-3.

${ }^{11}$ Dalam kasus ini terdapat dua Bank sebagai Kreditor pemegang jaminan kebendaan (Kreditor Separatis), yaitu Bank BNI dan Bank Syariah Mandiri.

${ }^{12}$ Surat Tim Kurator No. 002/Kurator.DJL-S/IX/2010 tertanggal 27 September 2010.
} 
DEWI JAYA LESTARI \& NY. SARINA yang dinyatakan pailit oleh Pengadilan Niaga pada Pengadilan Negeri Jakarta Pusat? (Studi kasus Putusan Nomor: 50/Pailit/2010/PN.Niaga.Jkt.Pst)?

b. Bagaimana upaya hukum yang dapat ditempuh oleh Bank BNI sebagai pemegang jaminan kebendaan agar CV. DEWI JAYA LESTARI \& NY. SARINA sebagai Debitor Pailit dapat melunasi utangnya?

Penelitian ini merupakan penelitian hukum empiris, yaitu berfokus pada masalah hukum (problem focused research) ${ }^{13}$ Perlindungan Hukum Terhadap Bank Sebagai Pemegang Jaminan Kebendaan Terkait Pelunasan Hutang Oleh Debitor. Dalam kasus yang hendak dianalisis, Bank BNI sebagai kreditor separatis atas harta pailit atau sebagai pemegang jaminan kebendaan, mengalami problema untuk mendapatkan haknya bagi pelunasan piutang. Sehingga Bank BNI harus berupaya memenuhi seluruh hak-haknya.

\section{PEMBAHASAN}

CV Dewi Jaya Lestari dan Ny. Sarina mengalami kondisi keadaan merugi dan akhirnya berhenti beroperasi pada akhir 2009. Saat itu masih ada tagihan untuk order pemesanan bahan baku plastik berupa biji plastik yang belum diselesaikan kepada CV Mekar Mandiri Plasindo. Hingga permohonan pailit diajukan, CV Dewi Jaya Lestari dan Ny. Sarina memiliki kewajiban kepada CV Mekar Mandiri Plasindo. ${ }^{14}$ Hutang CV Dewi Jaya Lestari dan Ny. Sarina kepada CV Mekar Mandiri Plasindo yang telah jatuh waktu dan dapat ditagih pada akhirnya tidak dibayar oleh CV Dewi Jaya Lestari dan Ny. Sarina. Akibatnya berdasarkan bukti surat tagihan sebagaimana sudah disebutkan di atas, CV Dewi Jaya Lestari dan Ny. Sarina berkewajiban untuk membayar lunas semua hutangnya kepada CV Mekar Mandiri Plasindo secara tunai sesuai dengan telah disepakati. CV Dewi Jaya Lestari dan Ny. Sarina meskipun telah ditagih berkalikali, namun tidak juga menyelesaikan kewajibannya. Kewajiban yang dimaksud tersebut dinyatakan dalam mata uang Indonesia dan kewajiban tersebut telah langsung ada dan wajib dipenuhi oleh CV Dewi Jaya Lestari dan Ny. Sarina. Bila tidak dipenuhi, maka konsekuensinya memberi hak kepada CV Mekar Mandiri

\footnotetext{
${ }^{13}$ Soerjono Soekanto, Pengantar Penelitian Hukum, (Jakarta, UI Press, 2010), hal. 10.

${ }^{14}$ Putusan Pailit Nomor: 50/Pailit/2010/PN.Niaga.JKT.PST, op.cit., hal. 3.
} 
Plasindo untuk mendapatkan pemenuhannya dari harta kekayaan CV Dewi Jaya Lestari dan Ny. Sarina. ${ }^{15}$ Ternyata CV Dewi Jaya Lestari dan Ny. Sarina tidak juga melaksanakan kewajibannya, sehingga jelas terbukti secara hukum berdasarkan Pasal 2 UU PKPU telah terpenuhi.

Berdasarkan hal-hal tersebut di atas, CV Mekar Mandiri Plasindo dan H. Sopiah memohon dengan hormat kepada Majelis Hakim yang terhormat agar berkenan memberikan putusan antara lain: menerima dan mengabulkan permohonan pailit yang diajukan oleh CV Mekar Mandiri Plasindo untuk seluruhnya; dan menunjuk dan mengangkat kurator dalam hal CV Dewi Jaya Lestari dan Ny. Sarina dinyatakan pailit atau selaku pengurus dalam CV Dewi Jaya Lestari dan Ny. Sarina masuk dalam proses penundaan kewajiban pembayaran utang.

Pengajuan kepailitan oleh CV Mekar Mandiri Plasindo dan H. Sopiah merupakan haknya selaku Kreditor yang berkepentingan untuk mendapatkan haknya bagian pelunasan piutangnya, sebab telah terjadi ketidakmampuan CV Dewi Jaya Lestari dan Ny. Sarina untuk membayar atas utang-utangnya terhadap CV Mekar Mandiri Plasindo dan H. Sopiah yang telah jatuh tempo. Ketidakmampuan tersebut telah disertai dengan suatu tindakan nyata atas permintaan CV Mekar Mandiri Plasindo dan H. Sopiah sebagai pihak ketiga.

Untuk mengajukan permohonan kepailitan tersebut, CV Mekar Mandiri Plasindo dan H. Sopiah telah memenuhi beberapa persyaratan, yaitu: (i) terdapat dua atau lebih kreditor, yaitu paling tidak CV Mekar Mandiri Plasindo dan H. Sopiah yang mempunyai piutang berdasarkan perjanjian atau berdasarkan undangundang, di mana piutang tersebut dapat ditagih di muka pengadilan; (ii) terdapat utang jatuh waktu dan dapat ditagih, yaitu kewajiban membayar utang telah jatuh waktu sebagaimana dijanjikan, sebab waktu penagihan dipercepat sebagaimana dijanjikan, sebab putusan pengadilan, arbiter, atau majelis arbitrase maupun penjatuhan sanksi atau denda yang dilakukan instansi berwenang; (iii) terdapat 
dua atau lebih kreditor yang disertai utang jatuh tempo yang dapat ditagih dapat secara sederhana dibuktikan. ${ }^{16}$

Dalam Putusannya, Majelis Hakim Pengadilan Niaga pada Pengadilan Negeri Jakarta Pusat menyatakan bahwa CV Mekar Mandiri Plasindo dan Ny. Sarina dalam keadaan pailit dengan segala akibat hukumnya. Putusan Pengadilan tersebut berdasarkan pertimbangan-pertimbangan hukum: (i) CV Mekar Mandiri Plasindo dan Ny. Sarina sebagai Debitor mempunyai dua atau lebih Kreditor, yaitu: CV Mekar Mandiri Plasindo dan H. Sopiahyang pedagang karung plastik; (ii) CV Mekar Mandiri Plasindo dan Ny. Sarina sebagai Debitor tidak membayar lunas sedikitnya satu orang; (iii) dan telah jatuh waktu dan dapat ditagih CV Mekar Mandiri Plasindo telah melakukan penagihan berkali-kali kepada Termohon, namun utang tersebut belum dibayar oleh termohon. ${ }^{17}$

Tiga pertimbangan Majelis Hakim tersebut dapat dinilai tepat, sebab semua unsur bagi persyaratan untuk dinyatakan pailit sebagaimana diatur dalam Pasal 2 ayat (1) UU PKPU. Menurut M. Hadi Shubhan, sebelum kreditor mengajukan permohonan pernyataan pailit terhadap debitor, syarat materiil yang harus dipenuhi oleh kreditor adalah adanya 1 (satu) orang yang telah jatuh waktu dan dapat ditagih, serta debitor memiliki setidak-tidaknya 2 (dua) kreditor. ${ }^{18}$ Dalam proses acara kepailitan, konsep utang tersebut sangat menentukan. Tanpa ada utang, tidak mungkin perkara kepailitan akan dapat diperiksa. Tanpa adanya utang, maka esensi kepailitan menjadi tidak ada, sebab kepailitan adalah pranata hukum untuk melakukan likuidasi aset debitor untuk membayar utang-utangnya terhadap para kreditornya. ${ }^{19}$ Tagihan dari CV Mekar Mandiri Plasindo secara hukum adalah utang atau kewajiban Termohon yang harus dibayar dan terbukti utang tersebut tidak dibayar oleh termohon. Dengan demikian unsur "Tidak membayar lunas sedikitnya satu utang” telah terpenuhi. Sebagai konsekuensinya,

\footnotetext{
${ }^{16}$ Bandingkan Titik Tejaninsih, Perlindungan Hukum Terhadap Kreditor Separatis dalam Pengurusan dan Pemberesan Harta Pailit, (Yogyakarta: FH UII, 2016), hal. 52-53. Persyaratan materiil untuk mengajukan permohonan pernyataan pailit adalah sangat sederhana, yaitu adanya utang yang jatuh tempo dan dapat ditagih yang belum dibayar lunas serta memiliki sekurangkurannya 2 (dua) kreditor. Adanya suatu utang akan dibuktikan oleh kreditor bahwa debitor mempunyai utang yang dapat ditagih karena sudah jatuh tempo ataupun dimungkinkan oleh perjanjiannya untuk dapat ditagih.

${ }^{17}$ Putusan Nomor: 50/Pailit/2010/PN.Niaga.Jkt.Pst, hal. 8.

${ }^{18}$ M. Hadi Shubhan, Hukum Kepailitan (Prinsip, Norma, dan Praktik di Peradilan), (Jakarta: Kencana Prenada Media Group, 2008), hal. 1.

${ }^{19}$ Ibid., hal. 34
} 
CV Dewi Jaya Lestari Ny. Sarina sebagai Debitor/Termohon harus dinyatakan pailit dengan segala akibat hukumnya.

Ditinjau dari Teori Penegakan Hukum, pemeriksaan sampai pada Putusan Pengadilan Niaga pada Pengadilan Negeri Jakarta Pusat merupakan bagian dari penegakan hukum Kepailitan, yaitu terjadinya proses berfungsinya norma hukum Kepailitan berdasarkan UU PKPU dan hukum kontrak/perjanjian berdasarkan KUH Perdata dalam realitanya. Proses peradilan di Pengadilan Niaga tersebut merupakan proses penegakan hukum Kepailitan dalam arti luas, yaitu melibatkan kreditor dan debitor sebagai subjek hukum dalam Kepailitan dalam semua hubungan hukum akibat kontrak atau perjanjian yang telah mereka lakukan.

Dalam kaitan dengan penegakan Hukum Kepailitan dalam pemeriksaan dan putusan kasus yang dianalisis meliputi penegakan hukum baik yang meliputi makna luas maupun sempit. Dalam makna luas penegakan hukum meliputi nilainilai keadilan bagi para pihak yang terkait dengan kasus, yaitu Debitor Pailit dan Bank BNI sebagai Kreditor pemegang hak jaminan kebendaan. Nilai-nilai keadilan tersebut telah tercakup dalam bunyi aturan formal dan nilai-nilai keadilan yang hidup dalam masyarakat bisnis dan perbankan. Dalam makna sempit, penegakan Hukum Kepailitan juga telah dilakukan yang meliputi penerapan terhadap peraturan formal atau tertulis sebagai instrumen hukum yang mengatur mengenai peristiwa dan penyelesaian kepailitan debitor pailit. ${ }^{20}$

Namun demikian ditinjau dari aspek efektivitas hukum, Bank BNI yang dalam kasus kepailitan ini selaku Kreditor pemegang jaminan kebendaan tidak dapat melaksanakan hak eksekusi secara sendiri terhadap jaminan kebendaan yang dimilikinya. Hal ini dikarenakan dalam pengaturan UU PKPU, jangka waktu pelaksanaan hak eksekusi adalah 90 hari atau 3 bulan. Tentu saja jangka waktu tersebut relatif amat singkat bagi Bank BNI untuk untuk mengeksekusi jaminan kredit, karena sering sulit mencari calon pembeli pada lelang atau penjualan umum.

${ }^{20}$ Ibid. Dalam makna luas penegakan hukum meliputi nilai-nilai keadilan yang tercakup di dalamnya bunyi aturan formal dan nilai-nilai keadilan yang hidup dalam masyarakat. Dalam makna sempit, penegakan hukum hanya meliputi penegakan peraturan formal dan tertulis saja. 
Mengacu pada Putusan Pengadilan Niaga pada Pengadilan Negeri Jakarta Pusat dalam Putusan No. 50/Pailit/2010/PN.Niaga.Jkt.Pst menyatakan bahwa batas akhir pengajuan tagihan tanggal 6 Oktober 2010 jam 15.00 WIB untuk dan atas nama Bank BNI, kemudian Bank BNI telah berupaya agar piutangnya dapat dibayarkan oleh debitornya tersebut. Terkait dengan upaya hukum ini, Bank BNI mengajukan total tagihan pinjaman Ny. Sarina melalui PT Sarana Citra Sukses sebagai Debitor Pailit.

Bank BNI sebagai Kreditor pemegang jaminan kebendaan berupaya melakukan penagihan setelah menerima surat dari Tim Kurator. Bank BNI tidak dapat melakukan hak eksekusinya mengingat waktu yang tersedia cukup singkat, namun demikian sebenarnya Putusan Pengadilan Niaga pada Pengadilan Negeri Jakarta Pusat dalam Putusan Pengadilan Niaga pada Pengadilan Negeri Jakarta Pusat dalam Putusan No. 50/Pailit/2010/PN.Niaga.Jkt.Pst. tanggal 23 Agustus 2010 yang menyatakan bahwa CV Mekar Mandiri Plasindo dan H. Sopiah dalam keadaan pailit dengan segala akibat hukumnya, sebenarnya telah memberikan kesempatan bagi Bank BNI untuk melakukan hak eksekusinya terhadap jaminan kredit, sehingga termasuk kategori terlindungi oleh Putusan Pengadilan Niaga tersebut.

Di sisi lain, tidak dapat dilakukannya eksekusi tersebut berakibat barang jaminan kebendaan harus diserahkan kepada kurator yang ditunjuk oleh pengadilan. Hal ini menjadi kurang efektif karena peraturan yang mengatur ternyata tidak dapat memenuhinya. Jadi ditinjau dari Teori Efektivitas Hukum, terjadi penyimpangan atau ketidaksesuaian dalam menerapkan ketentuanketentuan dalam UU PKPU yang mengatur mekanisme pemenuhan hak bank sebagai kreditor separatis atas harta pailit sebagai pelunasan hutang debitor pailit. Aturan yang memberikan hak kepada bank kreditor tidak dapat efektif karena ternyata hasil penjualan harta pailit debitor tidak mencukupi untuk pelunasan hutangnya. Pada pelaksanaan pembagian harta pailit, bank sebagai kreditor pemegang jaminan kebendaan memiliki hak istimewa atau didahulukan dalam pembayaran tagihan. Padahal Bank BNI sebagai pemegang jaminan kebendaan sebenarnya bisa melakukan haknya seperti tidak terjadi kepailitan. Keistimewaan kedudukan kreditor separatis tersebut telah tegas dinyatakan oleh 
undang-undang, yaitu berdasarkan suatu perjanjian pengikatan jaminan. Sebagai pemegang jaminan kebendaan, Bank BNI melakukan berbagai upaya bagi pemenuhan semua hak-haknya yaitu :

a. Upaya Bank BNI Ketika Kurator Melakukan Proses Pengurusan dan Pembereskan Harta Perusahaan Pailit

Tujuan utama kepailitan adalah untuk melakukan pembagian atas harta kekayaan debitor di antara para kreditor oleh kurator agar dapat menghindarkan terjadi sitaan terpisah atau eksekusi terpisah oleh kreditor dan menggantikannya dengan mengadakan sitaan bersama, sehingga kekayaan debitor dapat dibagi kepada semua kreditor sesuai dengan hak-hak masing. ${ }^{21}$ Dalam melaksanakan tugasnya dan tanggung jawabnya, Tim Kurator CV. Dewi Jaya Lestari dan Ny. Sarina (dalam pailit) melakukan beberapa tugas dan tanggung jawabnya untuk melakukan pemberesan harta pailit.

Kurator menghadap kepada hakim pengawas dan menyiapkan konsep pengumuman pailit serta mengusulkan nama surat kabar yang akan memuat pengumuman kepailitan. ${ }^{22}$ Kurator meminta salinan putusan pernyataan pailit, lalu segera memulai pengurusan atas seluruh harta pailit dan utang serta piutang harta pailit sebagaimana dimaksud dalam Pasal 19 UU PKPU, serta menginventarisir dan mencari harta palit. Pada hari yang telah ditentukan dalam rapat pertama kreditor yang dipimpin oleh Hakim Pengawas, Kurator menerima tagihan dari para kreditor. Kemudian pada tanggal yang telah ditentukan dalam pengumuman surat kabar, dilakukan rapat pencocokan utang piutang dan

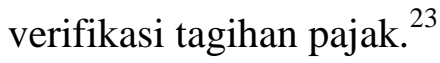

Kurator menanyakan kepada Debitor apakah akan mengajukan rencana perdamaian, yang bila ternyata tidak mengajukan rencana perdamaian namu ditolak oleh Kreditor, maka Debitor Pailit telah dalam status insolvensi. Terhadap harta pailit dilakukan appraisal (penilaian) oleh Kantor Jasa Penilai atas penetapan

\footnotetext{
${ }^{21}$ Imran Nating, Peranan dan Tanggung Jawab Kurator dalam Pengurusan dan Pemberesan Harta Pailit, Raja Grafindo Persada, Jakarta, 2004, hlm. 102.

${ }^{22}$ Wawancara dengan Muhammad Mukhlas, Kurator CV. Dewi Jaya Lestari dan Ny. Sarina (Dalam Pailit), dilakukan pada 8 Agustus 2018.

${ }^{23}$ Ibid.
} 
Hakim Pengawas. Lalu Kurator melakukan klasifikasi terhadap Kreditor menjadi: kreditor Separatis, kreditor preferen, dan kreditor konkuren. ${ }^{24}$

Penunjukkan kurator yang dilakukan oleh Pengadilan Niaga pada Pengadilan Negeri Jakarta Utara telah sesuai dengan ketentuan UU PKPU, di mana kurator sangat dibutuhkan dalam kepailitan. Kurator diangkat untuk menunaikan tugasnya dalam mengurus dan/atau membereskan harta pailit sejak tanggal putusan. ${ }^{25}$ Untuk juga memberikan perlindungan hukum yang berkepastian hukum, sejak tanggal putusan pailit, CV. Dewi Jaya Lestari dan Ny. Sarina (dalam pailit) kehilangan haknya untuk mengurusi dan mengelola harta milik yang termasuk harta pailit. Sejak Putusan Pengadilan Niaga, Tim Kurator langsung dapat menjalankan tugasnya melakukan pemberesan harta kepailitan, sebagaimana dimungkinkan oleh UU PKPU meskipun Putusan tersebut belum inkracht, yaitu terhadap Putusan tersebut masih dapat diajukan kasasi atau peninjauan kembali. ${ }^{26}$ Putusan Pengadilan Niaga pada Pengadilan Negeri Jakarta Pusat yang melakukan penunjukan Tim Kurator untuk melakukan pemberesan harta pailit tersebut merupakan bagian dari proses penegakan hukum oleh Pengadilan yang berwenang untuk memeriksa dan memutus perkara kepailitan.

Adapun beberapa tugas dan tanggung jawab Tim Kurator untuk melakukan pemberesan harta pailit sebagaimana dapat diuraikan sebagai berikut. Pertama, Tim Kurator CV. Dewi Jaya Lestari dan Ny. Sarina (dalam pailit) melakukan inventarisasi terhadap aset harta pailit. ${ }^{27}$ Inventarisasi terhadap aset-aset CV. Dewi Jaya Lestari dan Ny. Sarina (Dalam Pailit) dilakukan sebagai tugas Tim Kurator berdasarkan UU PKPU untuk kemudian menentukan mana yang masuk harta pailit dan mana yang bukan.

Kedua, Tim Kurator melakukan pelacakan harta dan mengumumkan pada dua Harian dan sekaligus mengumumkan: (i) rapat kreditor; (ii) batas akhir pengajuan tagihan; dan (iii) rapat verifikasi. Rapat Kreditor membuat kategori

${ }^{24}$ Ibid.

25 Agus Nurudin, "Menyoal tentang Honorarium Kurator/Pengurus Boedel Pailit dalam Pelaksanaan Kepailitan,” Jurnal Spektrum Volume 11/Nomor I/April 2014, hal. 3.

${ }^{26}$ Wawancara dengan Muhammad Mukhlas, Op.cit.

${ }^{27}$ Ibid. Ruang lingkup pemberesan Harta Pailit oleh Kurator berdasarkan Pasal 21 UU PKPU meliputi seluruh kekayaan Debitor pada saat putusan pernyataan pailit diucapkan serta segala sesuatu yang diperoleh selama kepailitan. Dengan demikian harta pailit juga meliputi segala sesuatu (harta) yang diperoleh selama kepailitan berlangsung. 
kreditor menjadi kreditor separatis dan kreditor konkuren. Bank BNI termasuk kategori kreditor separatis, sedangkan yang menjadi kreditor kongkuren adalah CV Mekar Mandiri Plastik dan H. Sopiah. ${ }^{28}$ Kurator telah mulai melakukan pelacakan terhadap harta pailit dan terus melakukannya sampai akhir kepalitan atau diangkatnya kepailitan diangkat. ${ }^{29}$

Selanjutnya dalam Rapat Verifikasi, Tim Kurator melakukan pencocokan utang/piutang dan verifikasi pajak. Namun, sampai dengan permohonan insolvensi diajukan oleh Tim Kurator, baik CV. Dewi Jaya Lestari maupun Ny. Sarina (Dalam Pailit) tidak pernah hadir. Konsekuensinya Tim Kurator tidak dapak melakukan penawaran rencana perdamaian. Pelaksanan Rapat Pencocokan Piutang tersebut sudah sesuai dengan ketentuan Pasal 113 ayat (1) huruf c UU PKPU yang menentukan bahwa paling lambat 14 (empat belas) hari setelah putusan pernyataan pailit diucapkan, Hakim Pengawas harus menetapkan hari, tanggal, waktu, dan tempat rapat Kreditor untuk mengadakan pencocokan piutang. Rapat Pencocokan tersebut juga dalam penerapan ketentuan Pasal 178 ayat (1) UU PKPU terkait status keadaan insolvensi harta pailit, yaitu bahwa jika dalam rapat pencocokan piutang tidak ditawarkan rencana perdamaian rencana yang ditawarkan tidak diterima, atau pengesahan perdamaian ditolak berdasarkan putusan yang telah memperoleh kekuatan hukum tetap, demi hukum harta pailit berada dalam keadaan insolvensi. Rapat Pencocokan Piutang juga merupakan penerapan dari asas perlindungan hukum, yaitu bahwa ketentuan mengenai jangka waktu maksimal dilakukannya proses pencocokan piutang CV Mekar Mandiri Plastik dan H. Sopian sebagai para Kreditor.

Dalam pengumuman kepailitan di dua surat kabar, dicantumkan agar seluruh kreditor termasuk tagihan dari kantor pajak menyampaikan tagihan kepada Kurator sesuai batas waktu yang ditentukan dalam pengumuman. Selanjutnya pada Rapat Pencocokan Utang Piutang dan Tagihan Pajak sesuai yang ditentukan dalam pengumuman koran, Kurator melakukan verifikasi seluruh

\footnotetext{
${ }^{28}$ Dokumen Rapat Tim Kurator CV. Dewi Jaya Lestari dan Ny. Sarina (Dalam Pailit), hlm.

${ }^{29}$ Wawancara dengan Muhammad Mukhlas, Op.cit.
} 1. 
tagihan kreditor, termasuk kreditor separatis yang di dalamnya termasuk tagihan pajak dan kreditor konkuren. ${ }^{30}$

Ketiga, Tim Kurator mengajukan permohonan insolvensi kepada hakim pengawas sebagai Debitor Pailit yang tidak hadir pada rapat kreditor, dan selanjutnya juga tidak pernah hadir. Akibatnya tidak ada upaya perdamaian. Setelah dilakukan rapat kreditor, yang ternyata Debitor Pailit tidak mengajukan rencana perdamaian, atau mengajukan rencana perdamaian tetapi ditolak oleh Kreditor atau Para Kreditor. Oleh karena itu dibuatlah berita acara insolvensi, namun ada juga hakim pengawas yang mengeluarkan Penetapan insolvensi setelah Kurator mengajukan pemohonan penetapan insolvensi kepada hakim pengawas. Kemudian hakim pengawas mengeluarkan penetapan $^{31}$ yang menyatakan bahwa Debitor Pailit CV Dewi Jaya Lestari dan Ny. Sarina dalam keadaaan insolvensi sejak tanggal 22 Oktober 2010, dan selanjutnya Kurator menyampaikan pemberitahuan kepada para Kreditor.

Berdasarkan Putusan Pengadilan Niaga, selanjutnya Kurator melakukan survei dan pendataan serta pelacakan aset harta pailit Kurator CV. Dewi Jaya Lestari dan Ny. Sarina (dalam pailit) dan melakukan road show ke beberapa kota tersebut untuk melakukan pengecekan aset harta pailit. Setelah jangka waktu dua bulan sejak debitor pailit dinyatakan insolvensi, para kreditor separatis tidak melakukan penjualan aset hak tanggungan.

Keempat, Tim Kurator melakukan pelelangan aset hak tanggungan. Untuk memperlancar proses pelelangan, Kurator melakukan kerja sama dengan sebuah balai lelang berdasarkan perjanjian kerja sama. Terkait dengan pelaksanaan lelang aset hak tanggungan, Kurator menyampaikan pengumuman lelang melalui dua surat kabar harian. ${ }^{32}$

Kelima, Tim Kurator melakukan pembagian hasil penjualan harta pailit berdasarkan hasil lelang yang dilakukan kepada masing-masing kreditor sesuai dengan daftar pembagian tahap ke- 1 dan bukti transfer. ${ }^{33}$ Untuk kepentingan

${ }^{30}$ Ibid.

${ }^{31}$ Surat Penetapan No. 50/pailit/2010/PN.Niaga.Jkt.Pst. tanggal 22 Oktober 2010

${ }^{32}$ Risalah Lelang Nomor: 357/2011 tanggal 06 April 2011 tanggal 06 April 2011.

${ }^{33}$ Wawancara dengan Muhammad Mukhlas, Op.cit. Harta Pailit yang telah dijual oleh Kurator, bila Harta Pailit tersebut diikat dengan jaminan kebendaan (misalnya jaminan Bank), maka hasil penjualan tersebut masuk kepada rekening Kurator, dan sebelum hasil penjualan 
pelaksanaan pembagian tersebut, Kurator mengajukan permohonan kepada Hakim Pengawas untuk melakukan rapat-rapat pembagian. ${ }^{34}$ Para Kreditor tidak ada yang berkeberatan terhadap daftar pembagian tahap kelima (tahap penutup) tersebut. Konsekuensinya daftar pembagian ke-5 tersebut menjadi mengikat dan kepailitan berakhir. Oleh karena itu selanjutnya Tim Kurator mengumumkan berakhirnya kepailitan atas Debitor Pailit CV. Dewi Jaya Lestari \& Ny. Sarina pada 2 (dua) surat kabar harian.

Keenam, Tim Kurator melakukan penjualan langsung atau di bawah tangan tidak melalui pelelangan atas aset CV Dewi Jaya Lestari dan Ny. Sarina (Dalam Pailit). Jaminan Pihak ke-3 yang dijadikan jaminan di Bank BNI dan PT Bank Syariah Mandiri. Sesuai ketentuan Pasal 185 ayat (1) UU PKPU, semua benda harus dijual di muka umum sesuai dengan tata cara yang ditentukan dalam peraturan perundang-undangan, namun dalam hal penjualan di muka umum sebagaimana dimaksud pada ayat (1) tersebut tidak tercapai maka penjualan di bawah tangan dapat dilakukan dengan izin Hakim Pengawas. ${ }^{35}$ Penjualan langsung tersebut dilakukan berdasar Penetapan Hakim Pengawas yang mengabulkan permohonan Kurator CV Dewi Jaya Lestari Ny. Sarina (Dalam Pailit) untuk melakukan penjualan langsung atas tujuh jaminan pihak ke-3. ${ }^{36}$

Ketujuh, Tim Kurator mengajukan permohonan penilaian ulang, sebab setelah melakukan pelelangan dan penjualan langsung, ternyata terdapat tiga aset harta pailit yang belum terjual meskipun penilaian terhadap harta pailit telah dilakukan cukup lama. Untuk mengatasi problema ini, Kurator melakukan

diserahkan kepada Bank (sebagai Kreditor Separatis) maka terlebih dahulu dikurangi oleh Kurator untuk Biaya Kepalilitan, misalnya: biaya pengumuman Koran, biaya appraisal, biaya operasional Kurator, dan fee Kurator. Daftar pembagian mana ditempel di dinding pengumuman Pengadilan Niaga Pada Pengadilan Negeri Jakarta Pusat, namun Kurator membuat pengumuman di Koran tentang adanya Daftar Pembagian yang telah ditempel pada dinding pengumuman pada Pengadilan Negeri tersebut. Para pihak yang berkepentingan atau memerlukannya dapat melihatnya, sedangkan Hakim Pengawas menandatangani dalam kolom mengetahui atas Daftar Pembagian tersebut.pe 2011.

${ }^{34}$ Pengumuman pada harian Pelita dan harian Ekonomi Neraca pada tanggal 26 Agustus

${ }^{35}$ Wawancara dengan Muhammad Mukhlas, Op.cit.

${ }^{36}$ Surat dari Muhammad Mukhlas dan Daniel P.P Simamora selaku Tim Kurator CV. Dewi Jaya Lestari \& Ny. Sarina (Dalam Pailit) aset jaminan pihak ke-3 CV. Dewi Jaya Lestari \& Ny. Sarina (dalam pailit) yang dijaminkan di Bank Negara Indonesia dan Bank Syariah Mandiri. 
penilaian ulang dengan terlebih dahulu mengajukan permohonan penilaian ulang dan melakukan seleksi terhadap beberapa calon jasa penilai. ${ }^{37}$

Kedelapan, Tim Kurator melakukan pengumuman berakhirnya kepailitan CV Dewi Jaya Lestari dan Ny. Sarina (dalam pailit), dengan terlebih dahulu Tim Kurator mengajukan permohonan persetujuan kepada Hakim Pengawas sesuai dengan ketentuan Pasal 202 ayat (2) jo. Pasal 15 ayat (4) UU PKPU, yang menentukan bahwa kurator melakukan pengumuman mengenai berakhirnya kepailitan dalam Berita Negara Republik Indonesia dan surat kabar dalam jangka waktu paling lambat 5 (lima) hari setelah tanggal putusan pernyataan pailit diterima oleh kurator dan hakim pengawas. ${ }^{38}$

Dalam rapat pembagian tahap terakhir, Tim Kurator menyampaikan daftar pembagian pada tahap tersebut kepada Bank BNI sebagai Kreditor pemegang jaminan kebendaan. Selanjutnya Tim Kurator melaksanakan peletakan daftar pembagian tersebut kepada Kepaniteraan Niaga pada Pengadilan Negeri Jakarta Pusat, serta pengumuman pada 2 (dua) surat kabar harian. Hingga berakhirnya tenggang waktu sebagaimana ketentuan Pasal 202 ayat (1) jo. Pasal 192 ayat (3) UU PKPU, ternyata pihak Kreditor tidak mengajukan keberatan atas Daftar Pembagian Kelima/Penutupan tersebut. Konsekuensinya, Daftar Pembagian Tahap kelima/Penutup telah menjadi mengikat.

Putusan Pengadilan Niaga pada Pengadilan Negeri Jakarta Pusat yang melakukan penunjukkan Kurator untuk melakukan tugas pemberesan harta kepailitan yang dilakukan Tim Kurator dimaksudkan juga agar terjadi efektivitas hukum Kepailitan. Tim Kurator dimaksudkan agar tujuan hukum Kepailitan dapat terwujud, yaitu melindungi Bank BNI sebagai Kreditor pemegang jaminan

37 Wawancara dengan Muhammad Mukhlas, Op.cit. Semua Harta Pailit baik bergerak maupun tidak bergerak sebelum dijual oleh Kurator harus dialakukan penilaian oleh Kantor Jasa Penilai (KJP), dan penjualan semua Harta harus dilakukan dimuka umum (dapat diartikan dengan lelang), dan bila cara tersebut tidak terjual maka dapat dilakuka penjualan di bawah tangan dengan ijin Hakim Pengawas. Dalam beberapa lama kemudian Kurator bisa mengajukan permohonan kepada Hakim Pengawas mohon Penetapan Penunjukan Kantor Jasa Penilai untuk melakukan penilaian ulang atas Harta Pailit tersebut.

38 Ibid. Apabila setelah dilakukan pelacakan atas Harta Pailit Milik Debitor Pailit dan ternyata sudah tidak ditemukan lagi dan semua Harta Pailit yang ada telah habis terjual dan juga telah dibagikan kepada Para Kreditor, maka Kurator mengajukan permohonan kepada Hakim Pengawas agar kepailitan diakhiri. Setelah Hakim Pengawas mengeluarkan penetapan tersebut, maka Kurator mengumumkan di dua Surat Kabar Harian tentang Pengakhiran Kepailitan dan mendaftarkan pada Lembaran Negera. 
kebendaan untuk memperoleh hak-haknya berkaitan dengan berlakunya asas yang menjamin hak-hak yang berpiutang dari kekayaan orang yang berutang. Putusan Kepailitan oleh Pengadilan Niaga pada Pengadilan Negeri Jakarta Pusat memungkinkan tujuan kepailitan dapat terlaksana sesuai tujuan Kepailitan untuk membagi seluruh kekayaan CV Dewi Jaya Lestari dan Ny. Sarina (dalam pailit). Dengan Putusan Kepailitan oleh Pengadilan tersebut, maka berlaku general statutory attachment atau seluruh kekayaan CV Dewi Jaya Lestari dan Ny. Sarina (dalam pailit) untuk kepentingan para Kreditor.

Dengan menggunakan Teori Penegakan Hukum, penyelesaian kasus kepailitan merupakan upaya untuk menerapkan norma-norma Hukum Kepailitan dan PKPU untuk menyelesaikan dan melakukan pemberesan harta pailit Debitor Pailit. Dalam penegakan hukum Kepailitan dan PKPU, Kurator telah melakukan tugas-tugas dan kewajibannya untuk memberikan perlindungan hukum bagi Bank BNI sebagai Kreditor pemegang jaminan kebendaan yang berhak untuk mendapatkan hak istimewa atau didahulukan dalam pemberesan harta pailit, melebihi kreditor-kreditor lain berdasarkan tingkatan kreditor. Namun dalam penerapan norma-norma hukum yang terkandung dalam UU PKPU nampaknya belum efektif bagi pemenuhan hak Bank BNI terhadap jaminan kebendaan atas hutang Debitor Pailit, meskipun misalnya Bank BNI telah berupaya dalam setiap tahapan pengurusan dan pemberesan atau pembagian harta pailit oleh Kurator.

b. Upaya Hukum Bank BNI Sebagai Pemegang Jaminan Kebendaan Bagi Pelunasan Piutangnya

Bank BNI sebagai pemegang jaminan kebendaan sebenarnya memilik hak untuk melakukan eksekusi haknya seolah-olah tidak terjadi kepailitan. Namun demikian UU PKPU telah membatasi jangka melaksanakan hak eksekusi atas jaminan kredit. Hal ini telah menyulitkan Bank BNI sebagai Kreditor untuk melakukan eksekusi aset yang dijaminkan oleh CV Dewi Jaya Lestari dan Ny. Sarina (dalam pailit). ${ }^{39}$ Hambatan yang dialami oleh Bank BNI dalam kasus ini jelas menunjukkan bahwa tidak tercapainya efektivitas hukum. Hans Kelsen

\footnotetext{
${ }^{39}$ Wawancara dengan Bapak Sufyedi, Manager Perkara Perdata Bank BNI Jakarta Pusat, dilakukan pada 13 Juli 2018. Bank BNI sebenarnya dapat bisa mengajukan upaya hukum tetapi, harus dilihat terlebih dahulu apakah asetnya masih ada atau tidak.
} 
berpandangan bahwa efektivitas hukum menentukan hukum berlaku atau tidak. ${ }^{40}$ Terhadap kasus kepailitan ini, ketentuan yang mengatur hak eksekusi bagi kreditor pemegang jaminan kebendaan tidak dapat diimplementasikan atau diterapkan. Jangka waktu untuk mengeksekusi aset jaminan kredit tersebut relatif amat singkat bagi bank termasuk bagi Bank BNI untuk mengeksekusi jaminan kredit, karena sering sulit mencari calon pembeli pada lelang atau penjualan umum. Tidak dapat dilakukannya eksekusi tersebut berakibat barang jaminan kebendaan harus diserahkan kepada kurator yang ditunjuk oleh pengadilan. Hal ini menjadi kurang efektif karena peraturan yang mengatur ternyata tidak dapat memenuhinya. ${ }^{41}$

Dengan demikian dalam pelaksanaan hak Bank BNI bagi pemenuhan haknya, terjadi hambatan-hambatan akibat mekanisme yang telah diatur dalam pemenuhan haknya sebagai Bank Kreditor atas harta pailit sebagai pelunasan hutang debitor pailit. ${ }^{42}$ Namun demikian, tidak ditemukan adanya itikad buruk Debitor Pailit misalnya dalam penyerahan sertipikat-sertipikat terkait jaminan kredit. Dengan demikian hambatan-hambatan pemenuhan hak-hak pelunasan piutang Bank BNI tidak disebabkan hal-hak terkait jaminan-jaminan kredit.

\footnotetext{
${ }^{40}$ Theo Huijbers, Filsafat Hukum dalam Lintasan Sejarah,( Yogyakarta: Kanisius, 2011), hal. 160-161.

${ }^{41}$ Wawancara dengan Bapak Sufyedi, Manager Perkara Perdata Bank BNI Jakarta Pusat, dilakukan pada 13 Juli 2018. Upaya hukum yang dapat ditempuh Bank BNI terkait pelunasan piutangnya ada ada 3 (tiga) alternatif, yaitu : (i) mengeksekui sendiri jaminan yang hak yang terlindungi berdasarkan nilai yang dijaminkan; (ii) gugat perdata yang prosesnya memakan waktu yang panjang, namun yang dalam hasil putusan nantinya kebanyakan mengatakan bahwa debitor melaksanakannya secara sukarela, bisa dilaksanakan ataupun tidak; dan (iii) kepailitan yang merupakan upaya yang paling efektif, karena ketika jaminan tidak tercover sudah ada lembaga kurator, sehingga Bank BNI merasa sudah terlindungi terutama kewajiban-kewajiban debitor. Bila Bank BNI mengeksekusi sendiri atas jaminan kreditnya, maka proses 2 (dua) bulan (90 hari) merupakan prose yang singkat, karena proses pailit merupakan proses yang panjang sehingga tidak cukup waktu tersebut.

${ }^{42}$ Ibid., Ada kalanya tidak semua hutangnya tertutupi. Komposisi hutang meliputi pokok utang, bunga dan denda. Jika dari pokok hutang tersebut tidak dibayar, maka kemudian ada tambahan bunga dan denda dari jumlah pokok tersebut. Bank BNI tidak menyatakan hutang debitor lunas jika pokok hutangnya tidak terpenuhi. Namun jika pokok hutangnya terpenuhi tapi bunga dan dendanya tidak semua dibayarkan, maka utang yang harus dibayarkan masih bisa dikurangi.
} 
c. Bank BNI Menghadiri Rapat-Rapat Pembagian Hasil Penjualan Harta Pailit sebagai Upaya Pelunasan Piutang

Dalam proses untuk mendapatkan pengembalian piutangnya, Bank BNI menghadiri beberapa rapat yang dilakukan terkait dengan pembagian hasil penjualan harta pailit. Rapat-rapat tersebut diselenggarakan oleh Kurator CV Dewi Jaya Lestari dan Ny. Sarina setelah mendapatkan dari ijin Hakim Pengawas. Bank BNI menghadiri rapat pembagian tahap ke-1. Dalam Rapat tersebut, Bank BNI mendapatkan daftar pembagian tahap ke-1 yang disiapkan oleh Tim Kurator. $^{43}$

Selanjutnya Bank BNI menghadiri rapat pembagian tahap ke-3, di mana pembagian yang dilakukan merupakan hasil penjualan sebagian harta pailit berupa satu unit rumah toko yang berlokasi di Jakarta Utara. Terkait dengan ini, Kurator melakukan pengumuman mengenai penyediaan daftar pembagian tahap ke-3 melalui media surat kabar harian Pelita dan harian ekonomi Neraca. Barang yang dilelang juga meliputi benda bergerak berupa besi tua melalui KPKNL yang terselenggara pada 27 April 2011.44

Bank BNI selanjutnya juga menghadiri rapat pembagian tahap ke-4 dilakukan setelah dilakukan penjualan beberapa harta pailit. Rapat ini dilakukan di Pengadilan Negeri Jakarta Pusat yang diikuti oleh Kreditor Separatis Bank Syariah Mandiri dan Bank BNI. Rapat pembagian diakhiri pada tahap ke-5 juga dihadiri oleh Bank BNI selaku Kreditor Separatis. Para Kreditor tidak ada yang berkeberatan terhadap daftar pembagian tahap kelima (tahap penutup) tersebut. Konsekuensinya daftar pembagian ke-5 tersebut menjadi mengikat dan kepailitan berakhir. Oleh karena itu selanjutnya Tim Kurator mengumumkan berakhirnya kepailitan atas Debitor Pailit CV. Dewi Jaya Lestari \& Ny. Sarina pada 2 (dua) surat kabar harian. ${ }^{45}$

\footnotetext{
${ }^{43}$ Pengumuman pada koran harian Kompas dan harian ekonomi Neraca pada tanggal 02 Mei 2011.

${ }^{44}$ Risalah Lelang Nomor: 359/2011.

${ }^{45}$ Wawancara dengan Bapak Sufyedi, Manager Perkara Perdata Bank BNI Jakarta Pusat, dilakukan pada 7 Agustus 2018, op.cit., Sepanjang kepentingan Bank BNI tetap terlindungi hakhaknya sebagai Bank Kreditor, maka Bank BNI tidak akan mengajukan keberatan terhadap daftar pembagian. Begitu juga sebaliknya. Bagi Bank BNI, kekuatan mengikat daftar pembagian pada tahap terakhir oleh Kurator adalah berdasarkan ketentuan UU PKPU, yaitu bahwa pembagian menjadi mengikat apabila terhadap Daftar Pembagian Hasil Penjualan Harta Pailit sebagai upaya pelunasan piutang tersebut tidak diajukan perlawanan atau perlawanan telah diputus oleh
} 
Sebagai Kreditor pemegang jaminan kebendaan, Bank BNI telah memperoleh pembagian yang diperoleh dari hasil penjualan harta pailit berdasarkan pengecualian terhadap prinsip atau asas paritas creditorium dan pari passu prorata parte, sebab terdapat alasan yang sah untuk didahulukan. Pengecualian tersebut merupakan pengecualian berlakunya: ketentuan dalam Pasal 1131 KUH Perdata yang memuatu prinsip paritas creditorium yang menyatakan bahwa segala kebendaan si berutang, baik yang bergerak maupun yang tidak bergerak, baik yang sudah ada maupun yang baru akan ada di kemudian hari, menjadi tanggungan untuk segala perikatan perseorangan; dan ketentuan Pasal 1132 KUH Perdata yang memuat prinsip dari pari passu prorata parte yang menyatakan bahwa kebendaan tersebut menjadi jaminan bersamasama bagi semua orang yang mengutangkan padanya, pendapatan, penjualan benda-benda itu dibagi-bagi menurut keseimbangannya, yaitu menurut besar kecilnya piutang masing-masing.

Tentu saja Bank BNI sebagai Kreditor pemegang jaminan kebendaan akan mengalami ketidakadilan dalam pembagian dari hasil penjualan harta pailit bila hanya diterapkan prinsip atau asas paritas creditorium dan pari passu prorata parte. Oleh sebab itu, terhadap Bank BNI tidak hanya diberlakukan atau diterapkannya prinsip paritas creditorium dan prinsip pari passu prorata parte, melainkan juga diterapkan prinsip structured creditors. Penerapan prinsip ini dalam pembagian harta Debitor Pailit untuk melunasi utang-utangnya terhadap Bank BNI selaku Kreditor Separatis nampaknya lebih berkeadilan dengan cara sesuai dengan proporsinya dan bukan dengan cara sama rata. ${ }^{46}$

Meskipun pembagian harta Debitor Pailit untuk melunasi utang-utangnya terhadap Bank BNI berdasarkan prinsip yang lebih berkeadilan tersebut, namun demikian tetap saja Bank BNI tidak dapat memperoleh seluruh haknya atau pelunasaan piutang terhadap Debitor Pailit. Kenyataannya, jumlah harta pailit lebih kecil daripada jumlah hutang, sehingga sisa outsanding yang tidak cukup mengakibatkan Bank BNI sebagai pemegang jaminan kebendaan akhirnya tetap menderita kerugian.

Pengadilan. Kurator juga berkewajiban untuk melaksanakan pembagian berdasarkan daftar pembagian yang telah mengikat tersebut.

${ }^{46}$ Lihat asas ini dalam Hadi Shubhan, Op.cit, hlm. 30. 


\section{d. Bank BNI Mengajukan Penagihan Terhadap Debitor Pailit}

Mengacu pada Putusan Pailit Pengadilan Niaga pada Pengadilan Negeri Jakarta Pusat, Bank BNI berupa menggunakan hak untuk memperoleh pelunasan piutang Debitor Pailit. Upaya ini dilakukan berdasarkan penetapan Pengadilan Niaga pada Pengadilan Negeri Jakarta Pusat yang menyatakan bahwa Debitor Pailit CV Dewi Jaya Lestari dan Ny. Sarina dalam keadaan insolvensi sejak tanggal 22 Oktober 2010. Upaya hukum yang tersedia bagi Bank BNI untuk mempergunakan haknya tersebut sesuai dengan ketentuan Pasal 59 ayat 1 dan ayat (2) jo. Pasal 55 ayat (1) UU PKPU yang pada intinya menentukan bahwa kreditor pemegang hak harus melaksanakan haknya tersebut dalam jangka waktu paling lambat 2 (dua) bulan setelah dimulainya keadaan insolvensi. ${ }^{47}$ Upaya hukum tersebut ditempuh oleh Bank BNI setelah mendapatkan surat dari Tim Kurator CV Dewi Jaya Lestari dan Ny. Sarina, perihal Pemberitahuan Penetapan Pengadilan Niaga pada Pengadilan Negeri Jakarta Pusat No. 50/Pailit/2010/PN.Niaga.Jkt.Pst. tanggal 22 Oktober 2010. Bank BNI mengajukan tagihan terhadap CV Dewi Jaya Lestari dan Ny. Sarina (dalam pailit) sebesar yang telah diakui oleh Tim Kurator.

Terkait dengan upaya penagihan oleh Bank BNI tersebut, Pasal 59 ayat (2) UU PKPU menentukan bahwa setelah lewat jangka waktu sebagaimana dimaksud pada ayat (1), kurator harus menuntut diserahkannya benda yang menjadi agunan untuk selanjutnya dijual sesuai dengan cara sebagaimana dimaksud dalam Pasal 185, tanpa mengurangi hak kreditor pemegang hak tersebut atas hasil penjualan agunan tersebut. Selanjutnya ketentuan Pasal 55 ayat (1) UU PKPU menyebutkan bahwa dengan tetap memperhatikan ketentuan sebagaimana dimaksud dalam Pasal 56, Pasal 57, dan Pasal 58, setiap kreditor pemegang gadai, jaminan fidusia, hak tanggungan, hipotek, atau hak agunan atas kebendaan lainnya, dapat mengeksekusi haknya seolah-olah tidak terjadi kepailitan.

Dengan menggunakan Teori Efektivitas Hukum, Instrumen hukum UU PKPU yang seharusnya memberikan perlindungan hukum bagi Bank BNI sebagai Kreditor pemegang jaminan kebendaan, akhirnya tidak dapat sepenuhnya dapat melakukan eksekusi haknya seolah-olah tidak terjadi kepailitan. Tidak efektifnya aturan perlindungan hak Bank BNI disebabkan aturan dalam UU PKPU yang

47 Surat Nomor: 011/Kurator.DJL-S/XI/2010 tertanggal 25 November 2010 dan Surat Nomor: 012/Kurator.DJL-S/XI/2010 tertanggal 25 November 2010. 
membatasi jangka melaksanakan hak eksekusi atas jaminan kredit, sehingga menyulitkan Bank BNI untuk melakukan penjualan terhadap harta jaminan kredit Debitor Pailit akibat sulit mencari calon pembeli pada lelang atau penjualan umum. Akibatnya, barang jaminan kebendaan harus diserahkan kepada kurator. Dengan demikian telah terjadi hambatan-hambatan akibat mekanisme yang telah diatur dalam pemenuhan haknya sebagai Bank Kreditor baga pelunasan hutang debitor pailit. Terkait dengan efektivitas hukum ini, berdasarkan pemikiran Hans Kelsen, efektivitas hukum Kepailitan tidak dapat sepenuhnya diberlakukan. ${ }^{48}$

Kepailitan atau sita umum dalam rezim hukum harta kekayaan merupakan pelaksanaan prinsip paritas creditorium dan prinsip pari passu prorata parte. ${ }^{49}$ Prinsip paritas creditorium dianut dalam sistem hukum perdata di Indonesia sebagaimana terdapat dalam Pasal 1131 KUH Perdata yang menyatakan bahwa segala kebendaan si berutang, baik yang bergerak maupun yang tidak bergerak, baik yang sudah ada maupun yang baru akan ada di kemudian hari, menjadi tanggungan untuk segala perikatan perseorangan. Sedangkan, prinsip dari pari passu prorata parte termuat dalam Pasal 1132 KUH Perdata, yang menyatakan bahwa kebendaan tersebut menjadi jaminan bersama-sama bagi semua orang yang mengutangkan padanya, pendapatan, penjualan benda-benda itu dibagi-bagi menurut keseimbangannya, yaitu menurut besar kecilnya piutang masing-masing, kecuali apabila di antara para berpiutang itu ada alasan-alasan yang sah untuk didahulukan. ${ }^{50}$ Dengan demikian, kepailitan adalah pelaksanaan lebih lanjut dari ketentuan pada Pasal 1131 dan Pasal 1132 KUH Perdata.

Dengan demikian, rasio pembagian secara pari passu prorata parte adalah bahwa kepailitan merupakan jatuhnya sita umum atas semua harta benda debitor kemudian dilakukan proses likuidasi atas seluruh harta benda debitor tersebut. Kemudian dibagi-bagikan hasil perolehannya kepada semua kreditornya sesuai dengan tata urutan tingkat kreditor sebagaimana diatur dalam undang-undang, ${ }^{51}$

\footnotetext{
${ }^{48}$ Theo Huijbers, Op.cit, hlm. 160-161.

${ }^{49}$ Kartini Mulyadi, "Kepailitan dan Penyelesaian Utang Piutang", dalam Rudhy Lontoh, Penyelesaian Utang Piutang Melalui Pailit atau Penundaan Kewajiban Pembayaran Utang, (Alumni: Bandung, 2001), hlm. 168.

${ }^{50}$ Hadi Shubhan, Op.cit., hlm. 5.

${ }^{51}$ Sutan Remi Syahdeini, Hukum Kepailitan, Memahami Faillissementsverordering Juncto Undang-Undang No. 4 Tahun 1998, (Jakarta: PT. Pustaka Utama Grafiti, 2002), hal. 16.
} 
kecuali apabila di antara para kreditornya, terdapat yang harus didahulukan menurut ketentuan Pasal 1132 KUH Perdata.

\section{PENUTUP}

\section{Kesimpulan}

a. Perlindungan hukum terhadap Bank BNI sebagai pemegang jaminan kebendaan untuk memperoleh pelunasan piutang terhadap CV. DEWI JAYA LESTARI \& NY. SARINA yang dinyatakan pailit oleh Pengadilan Niaga pada Pengadilan Negeri Jakarta Pusat bahwa Undang-Undang yang mengatur tidak cukup melindungi kepentingan Bank selaku Kreditor Separatis terutama dalam hal ketika, hutang dari debitur ternyata tidak cukup untuk memenuhi pelunasan piutangnya, selain itu dalam UndangUndang Nomor 37 Tahun 2004 tersebut tidak cukup melindungi kepentingan dari Bank BNI sebagai Kreditor Separatis dikarenakan adanya hal yang bertentangan dalam Pasal 55 ayat (1) UU PKPU dengan Pasal 56 kurang sejalan dengan ketentuan Hukum Jaminan dan ketentuan Hukum kepailitan itu sendiri. Sehingga kondisi ini dapat menimbulkan konflik apabila terjadi penafsiran atau pemahaman yang berbeda antara Kreditor separatis dengan Kurator.

b. Berdasarkan analisa, maka terdapat beberapa upaya hukum yang dapat ditempuh oleh Bank BNI sebagai pemegang jaminan kebendaan agar CV. DEWI JAYA LESTARI \& NY. SARINA sebagai Debitor Pailit dapat melunasi utangnya adalah dengan cara: mengeksekusi secara langsung terhadap jaminan kebendaan,melakukan gugatan secara Perdata, melakukan proses kepailitan.

\section{Saran}

a. Presiden dan Dewan Perwakilan Rakyat (DPR) disarankan untuk melakukan revisi terhadap aturan dalam UU PKPU yang mengatur mengenai jangka waktu bagi kreditor separatis/preferen untuk melaksanakan hak eksekutorial terhadap jaminan kebendaan miliknya. Jangka waktu yang diberikan kepada kreditor separatis untuk melakukan hak eksekusi sejak debitor pailit dinyatakan dalam keadaan insolvensi hendaklah diperpanjang jangka 
waktunya sesudah dimulai insolvensi yang relatif amat singkat bagi bank untuk mengeksekusi jaminan kredit.

b. Presiden dan Dewan Perwakilan Rakyat (DPR) disarankan untuk melakukan revisi terhadap aturan dalam UU PKPU yang mengatur mengenai kurator yang diangkat oleh Pengadilan Niaga untuk menunaikan tugasnya dalam mengurus dan/atau membereskan harta pailit sejak tanggal putusan pailit. Revisi dimaksudkan agar Tim Kurator dapat lebih efektif dalam melaksanakan kepailitan sebagaimana maksud dan tujuan hukum Kepailitan, yaitu melindungi Kreditor Preferen/Separatis untuk memperoleh hak-haknya berkaitan dengan berlakunya asas yang menjamin hak-hak yang berpiutang dari kekayaan orang yang berutang.

c. Mengingat semakin marak terjadi kepailitan, kepada bank sebagai kreditor pemegang jaminan kebendaan disarankan melengkapi dengan regulasi dan persyaratan-persyaratan tambahan guna melindungi kepentingannya bagi pelunasan seluruh piutangnya ketika terjadi kepailitan debitornya.

d. Bank sebagai pemegang jaminan kebendaan disarankan membuat akta tambahan untuk mengamankan aset-aset jaminan kredit sebagai antisipasi bila terjadi kepailitan atas debitornya. 


\section{DAFTAR PUSTAKA}

\section{Buku}

Black's Law Dictionary. Pada https://thelawdictionary.org. Diakses 10 Oktober 2018.

Huijbers, Theo. Filsafat Hukum dalam Lintasan Sejarah, Yogyakarta: Kanisius, 2011.

Jono. Hukum Kepailitan, Jakarta: Sinar Grafika, 2008,

Kompas, Pengumuman pada koran harian Kompas dan harian ekonomi Neraca pada tanggal 02 Mei 2011.

Lontoh, Rudhy. Penyelesaian Utang Piutang Melalui Pailit atau Penundaan Kewajiban Pembayaran Utang, Bandung: Alumni, 2001.

Nating, Imran. Peranan dan Tanggung Jawab Kurator dalam Pengurusan dan Pemberesan Harta Pailit, Jakarta: Raja Grafindo Persada, 2012.

Sastrawidjaja, Man S. Hukum Kepailitan dan Penundaan Kewajiban Pembayaran Utang, Bandung: PT Alumni, 2006.

Sjadeini, Remi Sutan, "Memahami Undang-Undang No. 37 Tahun 2004 Tentang Kepailitan.” Cet III, Jakarta: Grafiti, 2010.

Shubhan, M. Hadi. Hukum Kepailitan (Prinsip, Norma, dan Praktik di Peradilan), Jakarta: Kencana Prenada Media Group, 2008.

Tejaningsih, Titik. Perlindungan Hukum Terhadap Kreditor Separatis dalam Pengurusan dan Pemberesan Harta Pailit, Yogyakarta: FH UII, 2016.

Nurudin, Agus. "Menyoal tentang Honorarium Kurator/Pengurus Boedel Pailit dalam Pelaksanaan Kepailitan." Jurnal Spektrum Volume 11 Nomor I, April 2014, hal. 3.

\section{Peraturan Perundang-Undangan}

Indonesia. Undang-Undang Tentang Kepailitan dan Penundaan Kewajiban Pembayaran Utang. UU No. 37 Tahun 2004, LN Tahun 2004 No. 131, TLN Nomor 4443

Indonesia. Undang-Undang Tentang Perbankan. UU No. 7 Tahun 1992, LN Tahun 1992 No. 32, TLN Nomor 3817.

Indonesia. Undang-Undang Tentang Hak Tanggungan Atas Tanah Beserta Benda-Benda yang Berkaitan Dengan Tanah. UU No. 4 Tahun 1996, LN. Tahun 1996 No. 42, TLN Nomor 3632.

Putusan Pailit Nomor: 50/Pailit/2010/PN. Niaga.Jkt.Pst.

Penetapan Nomor: 50/Pailit/2010/PN.Niaga.Jkt.Pst., tanggal 22 Oktober 2010.

Risalah Lelang Nomor: 357/2011 tanggal 06 April 2011 tanggal 06 April 2011 . 